\title{
Rasnitsynoryctes alexandri gen. et sp.n., a new genus and species of the subfamily Doryctinae (Hymenoptera: Braconidae) from Malaysia
}

\author{
Rasnitsynoryctes alexandri gen. et sp.n. - новый род и виА \\ браконид подсемейства Doryctinae (Hymenoptera: Braconidae) \\ из Махайзии
}

\author{
S.A. Belokobylskij \\ С.А. Белокобыльский
}

Zoological Institute, Russian Academy of Sciences, St. Petersburg 199034, Russia; Museum and Institute of Zoology PAN, Wilcza 64, 00679 Warsaw, Poland. E-mail: sb@zin.ru, doryctes@yahoo.com

Зоологический институт Российской академии наук, С.-Петербург 199034, Россия; Музей и институт зоологии ПАН, Вильча 64 , 00-679 Варшава, Польша.

KEY WORDS: Hymenoptera, Braconidae, Doryctinae, new genus and species, Malaysia.

КЛЮЧЕВЫЕ СЛОВА: Нуmenoptera, Braconidae, Doryctinae, новые род и вид, Малайзия.

\begin{abstract}
A new genus, Rasnitsynoryctes gen.n., with the type species $R$. alexandri sp.n., from Malaysian Peninsula is described and illustrated. The main diagnostic characters of the new genus are the short mediocubital cell of the hind wing, presence of the two longitudinal lateral furrows on the second metasomal tergite, the transformed inner tibial spur of the hind leg, and dense pubescence over the most part of the body. The comparisons of the new genus with Neotropical and Oriental Pedinotus Szepligeti, Afrotropical Doryctoproctus Belokobylskij, and Oriental Halycaea Cameron are given.
\end{abstract}

РЕЗЮМЕ. Описывается и иллюстрируется новый род Rasnitsynoryctes gen.n. с типовым видом $R$. alexandri sp.n. с Малайского полуострова. Основными диагностическими признаками нового рода являются: короткая медиокубитальная ячейка заднего крыла, второй тергит брюшка с двумя продольными боковыми бороздками, преобразованная внутренняя шпора задней ноги и большей частью густо и почти сплошь опушенное тело. Показаны отличия нового рода от неотропически-ориентального Pedinotus Szepligeti, афротропического Doryctoproctus Belokobylskij и ориентального Halycaea Cameron.

\section{Introduction}

The subfamily Doryctinae is one of the most diverse groups of the braconid parasitic wasps; it is widespread on almost all continents. Tropical and subtropical faunas of this subfamily of the Old World are poorly investigated even at the genus level, with a possible exception of the fauna of the Australasian Region [Belokobylskij et al., 2004]. Consequently, current discoveries of new taxa of the subfamily Dorycti- nae in the Oriental and Afrotropical Regions are becoming common [Belokobylskij, 2002a, 2005a, b, 2006, 2008a, b; Belokobylskij, Chen, 2006; etc.].

The new genus Rasnitsynoryctes described below belongs to the group of Old and New World genera of the tribe Doryctini that have the short mediocubital cell in the hind wing and the double longitudinal lateral furrow on the second metasomal tergite, viz. the Neotropical Gymnobracon Szepligeti, 1902, Osmophila Szepligeti, 1902, and Hybodoryctes Szepligeti, 1906, the Neotropical and Oriental Pedinotus Szepligeti, 1902 (with the subgenera Pedinotus s.s. and Eopedinotus Belokobylskij, 2005), the Afrotropical Doryctoproctus Belokobylskij, 2005, and the Oriental Halycaea Cameron, 1903. Rasnitsynoryctes gen.n. is mainly characterized by the undoubtedly apomorphic modification of the inner spur of hind tibia with a subapical expansion on its inner surface.

This paper and the name of the new genus and species are dedicated to Professor Alexandr Pavlovich Rasnitsyn, a famous Russian palaeoentomologist and evolutionist, in honor of his 75th anniversary.

For terminology of the morphological features and sculpture, measurements and wing venation nomenclature, see Belokobylskij and Maeto [2009]. The holotype of the new species is deposited in the Zoological Institute of the Russian Academy of Sciences (St. Petersburg, Russia).

\section{Systematic part}

\section{Rasnitsynoryctes gen.n.}

Type species: Rasnitsynoryctes alexandri sp.n.

ETYMOLOGY. Combination of Prof. A.P. Rasnitsyn's surname and doryctine generic name, Doryctes Haliday, 1836. Gender is masculine. 

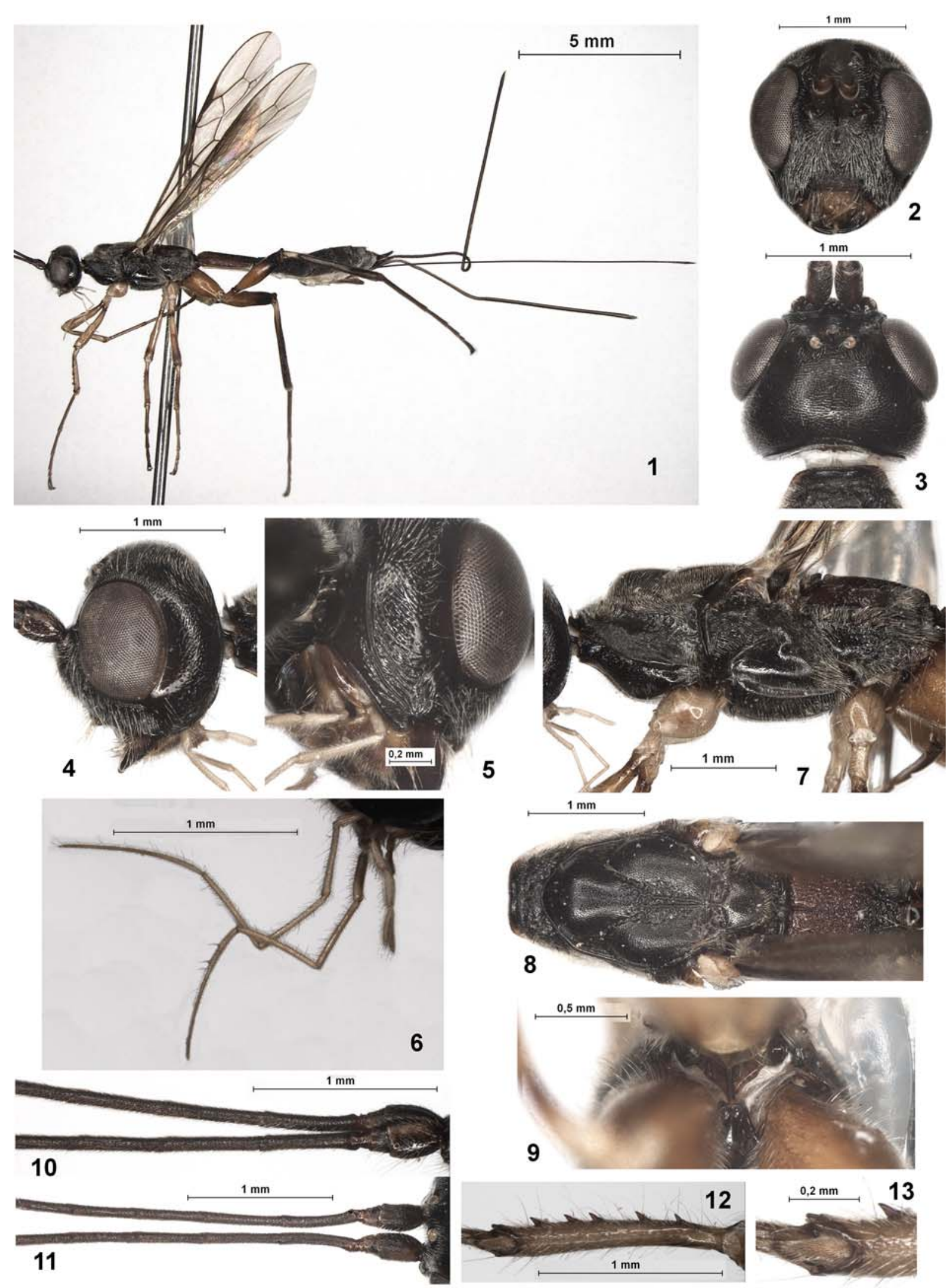

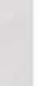

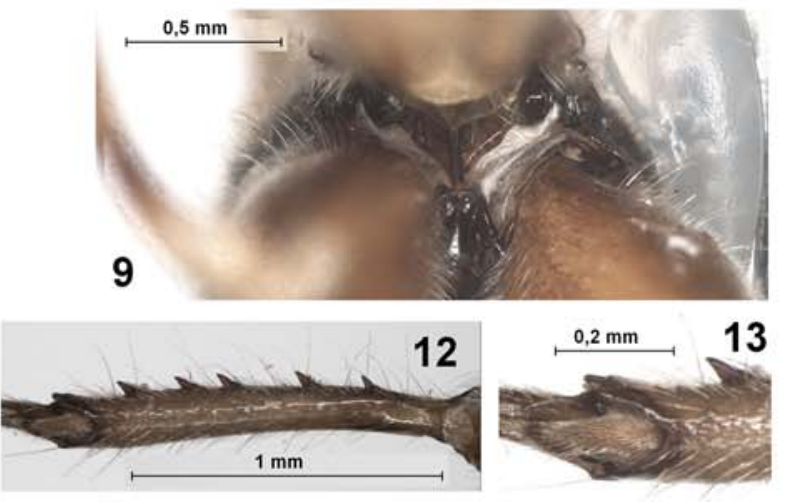


DIAGNOSIS. New genus, Rasnitsynoryctes gen.n., resembles Pedinotus (including its Oriental subgenus Eopedinotus [Belokobylskij, 2005a]), but differs in having second flagellar segment longer than first segment (shorter in members of Pedinotus), hind wing with five hamuli (only three in members of Pedinotus), third tergite without additional transverse furrow (with transverse furrow in members of Pedinotus), inner spur of hind tibia with distinct expansion in its inner apical third (simple in members of Pedinotus), discoidal cell sessile anteriorly (petiolate anteriorly in members of Pedinotus), and spiracles of fore tergites situated in basal 0.25 (in basal 0.3 in members of Pedinotus). This new genus is also similar to Afrotropical Doryctoproctus [Belokobylskij, 2005a], but differs in having hind coxa not elongate, with distinct basoventral corner and tubercle (coxa elongate, without basoventral corner and tubercle in Doryctoproctus), second flagellar segment longer than first segment (shorter in Doryctoproctus), hind wing with five hamuli (only with three hamuli in Doryctoproctus), inner spur of hind tibia with distinct expansion in its inner apical third (simple spur in Doryctoproctus), discoidal cell anteriorly sessile (anteriorly petiolate in Doryctoproctus), and sides of pronotum without round tubercles (with distinct round tubercles in Doryctoproctus). Rasnitsynoryctes gen.n. distinctly differs from Oriental Halycaea [Belokobylskij, $2002 \mathrm{~b}$ ] in having furrows of second metasomal tergite weakly converging and independently fused to second suture (strongly converging and fused near middle of second suture in Halycaea), second suture with two distinct lateral breaks (with more or less distinct single medial break in Halycaea), fore tibia with coarse and sparse spines (usually without spines, or sometimes with very small spines in Halycaea), inner spur of hind tibia with distinct expansion in its inner apical third (simple in Halycaea), discoidal cell anteriorly sessile (anteriorly petiolate in Halycaea), and almost entirely and densely setose tergites in apical half of metasoma (these tergites with single subapical lines of setae in Halycaea).

DESCRIPTION. Head (Figs 2-4) not depressed, weakly transverse. Ocelli arranged in obtuse triangle (Fig. 3). Frons weakly concave, with fine median keel. Eyes glabrous. Occipital carina dorsally complete but fine, obliterate below at long distance above hypostomal carina (Fig. 5). Malar suture almost absent. Clypeus with distinct lower flange, bordered medially and laterally by fine carina. Hypoclypeal depression medium and subrounded. Postgenal bridge rather wide (Fig. 5). Maxillary palpi long, 6-segmented, their sixth (apical) segment 1.5 times longer than fifth segment (Fig. 6); labial palpi short, 4-segmented, their third segment not shortened (Fig. 6). Scape of antenna (Figs $10,11)$ wide and short, without apical lobe or basal constriction. First flagellar segment subcylindrical, weakly outcurved, slightly shorter than second segment.

Mesosoma (Fig. 7) not depressed. Neck of promesosoma short. Pronotum distinctly convex dorsally, its anterior flange upcurved; pronotal carina very fine. Propleural lobe long and narrow, without transparent flange. Mesonotum not highly and roundly elevated above pronotum. Median lobe of mesonotum without median longitudinal furrow and anterolateral shoulders. Notauli deep, complete, rather wide (Fig. 8). Tegula distinctly widened distally. Prescutellar depression short, with median carina. Scuto-scutellar suture distinct. Scutellum weakly convex, without lateral carinae. Metanotum with short median tooth. Sternaulus (precoxal sulcus) shallow, narrow, long, weakly curved, finely punctate (Fig. 7). Prepectal carina distinct and complete, wide ventrally. Postpectal carina absent. Metapleural flange short, rather wide, subpointed apically. Propodeum with finely delineated areas; lateral tubercles and propodeal bridge (Fig. 9) absent. Propodeal spiracles rather small and oval. Metapleural suture distinct.

Wings (Figs 14-17). Pterostigma of fore wing rather narrow. Radial vein arising slightly before middle of pterostigma. Radial cell not shortened. Both radiomedial veins present. Recurrent vein weakly antefurcal. Nervulus postfurcal. Discoidal cell sessile. Parallel vein arising from posterior 0.2 of apical margin of brachial cell. Brachial cell closed postero-apically by brachial vein. Transverse anal veins absent. Hind wing with 5 hamuli (Fig. 18). First abscissa of costal vein 0.5 times as long as second abscissa. Radial vein arising from costal vein at a distance from basal vein. Radial cell weakly diverging posteriorly, without additional transverse vein. Medial cell narrow in basal 0.3 , distinctly widened towards apex, 7.8 times longer than wide, 0.5 times as long as hind wing. Nervellus present. Submedial cell small. Mediocubital vein curved, its first abscissa 0.35 times as long as second abscissa. Recurrent vein short, distinctly oblique toward base of wing.

Legs. Fore tibia with six short and thick spines arranged in almost single row (Fig. 12). Middle tibia with four or five short and thick spines. Hind coxa (Fig. 20) large, with distinct basoventral tooth. All femora with distinct dorsal protuberances. Hind tibia with apical comb of spines on its outer margin. Hind tibia with short spurs; its inner spur distinctly curved and with inner expansion in apical third (Figs 23, 24). Hind basitarsus 0.9 times as long as second to fifth segments combined. Claws small and simple (Fig. 22).

Figs 1-13. Rasnitsynoryctes alexandri gen. et sp.n. (holotype, female). 1 - habitus, lateral view; 2 - head, front view; 3 - head, dorsal view; 4 - head, lateral view; 5 - head (partly), posteroventral view; 6 - palpi; 7 - mesosoma, lateral view; 8 - mesosoma, dorsal view; 9 - propodeum, posterior view; 10 - basal segments of antenna, lateral view; 11 - basal segments of antenna, dorsal view; 12 - fore tibia, lateral view; 13 - spur of fore tibia.

Рис. 1-13. Rasnitsynoryctes alexandri gen. et sp.n. (голотип, самка). 1 - общий вид сбоку; 2 - голова спереди; 3 - голова сверху; 4 - голова сбоку; 5 - часть головы, вид сзади и снизу; 6 - щупики; 7 - мезосома сбоку; 8 - мезосома сверху; 9 проподеум, вид сзади; 10 - базальные членики усиков, вид сбоку; 11 - базальные членики усиков, вид сверху; 12 - передняя голень сбоку; 13 - шпора передней голени. 

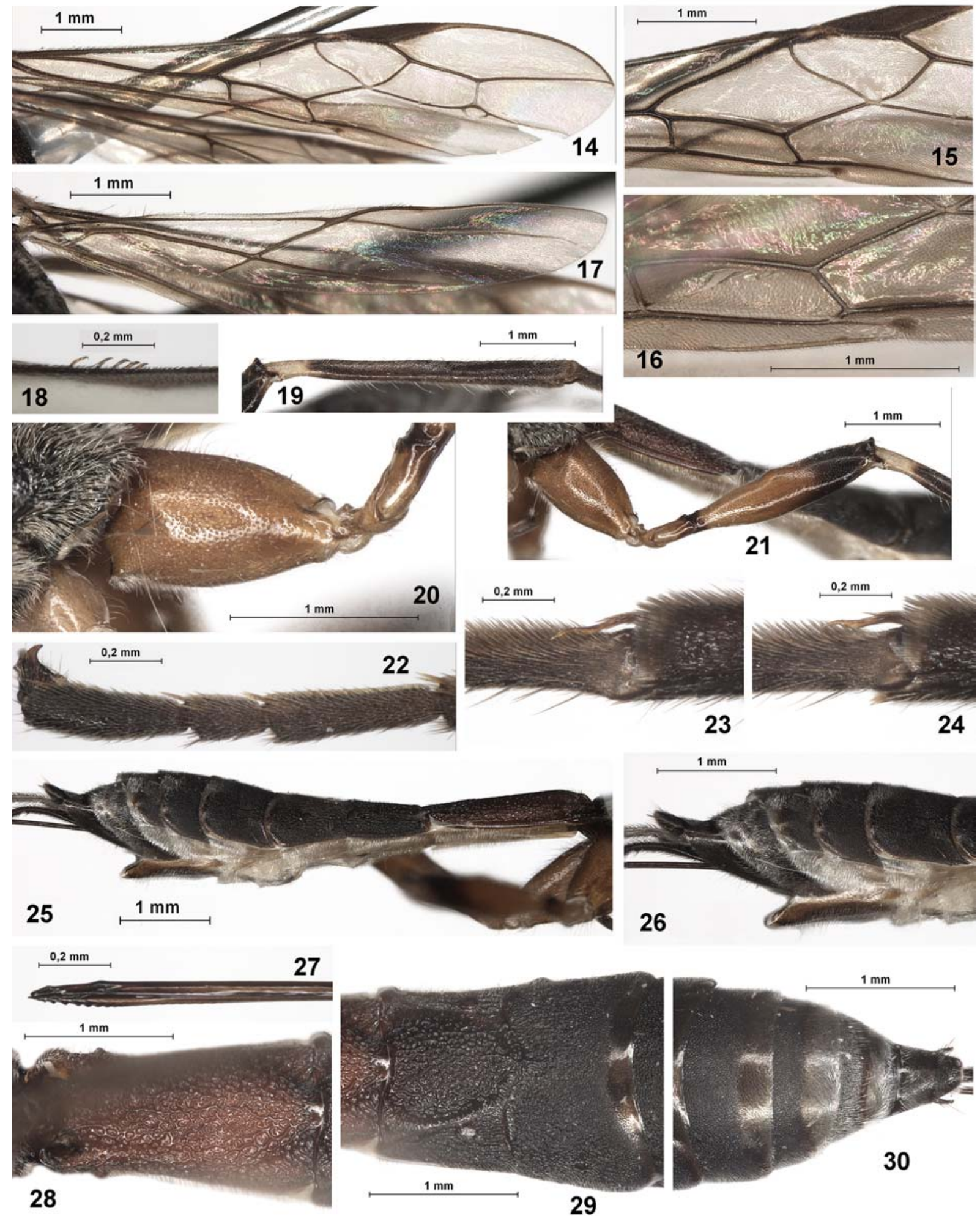

Figs 14-30. Rasnitsynoryctes alexandri gen. et sp.n. (holotype, female). 14 - fore wing; 15 - median part of fore wing; 16 brachial cell of fore wing; 17 - hind wing; 18 - hamuli; 19 - hind tibia; 20 - hind coxa; 21 - hind coxa, trochanter, trochantellus and femur; 22 - three apical segments of hind tarsus; 23, 24 - inner spur of hind tibia; 25 - metasoma, lateral view; 26 - apical part of metasoma, lateral view; 27 - tip of ovipositor, lateral view; 28 - first metasomal tergite, dorsal view; 29 - second and third metasomal tergite, dorsal view; 30 - apical metasomal tergites, dorsal view. 
Metasoma (Figs 25, 26, 28-30). First tergite not petiolate, long and wide (Fig, 28). Acrosternite of first segment short and with high median keel, 0.15 times as long as first tergite. Dorsope of first tergite large; basolateral lobes present but short; spiracular tubercles small and situated in basal 0.25 of tergite; dorsal carinae present only basally. Lateral furrows of second tergite deep, wide, weakly converging posteriorly, fused with second suture (Fig. 29). Second suture rather deep, narrow, widely curved medially, with wide lateral gaps (Fig. 29). Second to sixth tergite with separate laterotergites (Fig. 25). All tergites and laterotergites covered with very dense and short white setae. Apex of ovipositor with two obtuse and small dorsal nodes (Fig. 27). Ovipositor sheath longer than metasoma (Fig. 1).

DISTRIBUTION. Oriental Region.

\section{Rasnitsynoryctes alexandri sp.n.} Figs 1-30.

TYPE MATERIAL. Holotype: female, "Air Hitam Forest Res., U.P.M., Selangor, Peninsula Malaysia, 28. vii - 4. viii, 1992 , Coarse Malaise Trap" (ZISP).

DESCRIPTION. Female. Body length $10.4 \mathrm{~mm}$; fore wing length $7.5 \mathrm{~mm}$.

Head width 1.35 times its median length, 1.2 times as wide as mesoscutum. Head behind eyes roundly narrowed in dorsal view. Transverse diameter of eye 1.5 times longer than temple. Ocelli of medium size, in triangle with base 1.3 times its sides, situated distinctly before median line of eyes. POL 1.5 times OD, 0.75 times OOL. Eye with small emargination opposite antennal sockets, 1.3 times as high as broad. Malar space height 0.3 times height of eye, 0.7 times basal width of mandible. Face width 0.9 times height of eye and 1.2 times height of face and clypeus combined. Clypeus weakly convex. Width of hypoclypeal depression 1.3 times distance from edge of depression to eye, 0.6 times width of face. Hypostomal flange narrow.

Antenna slender, weakly setiform, more than 45segmented (apical segments missing). Scape 1.3 times longer its maximum width. First flagellar segment 6.2 times longer its apical width, 0.9 times as long as second segment. Subapical segments about 4.0 times longer their width.

Mesosoma. Length 2.3 times its height. Median lobe of mesoscutum convex, distinctly protruding forward and rounded anteriorly. Notauli deep anteriorly and more shallow posteriorly, crenulate. Prescutellar depression rather deep, with median carina, almost smooth, 0.3 times as long as scutellum. Sternaulus (precoxal sulcus) anteriorly not connected to prepectal carina, shallow and narrow, running along anterior 0.8 of lower part of mesopleuron. Metapleural lobe with dense white pubescence along posterior margin.
Wings. Fore wing about 4.0 times longer its maximum width. Pterostigma 4.6 times longer its width. Metacarp 1.4 times longer than pterostigma. First and second radial abscissae form very obtuse angle. Second radial abscissa 2.8 times longer than first abscissa, about 0.5 times as long as almost straight third abscissa, 1.5 times longer than curved first radiomedial vein. Second radiomedial cell rather short, 2.8 times longer than its maximum width, 1.1 times longer than width of brachial cell. First medial abscissa distinctly sinuate. Recurrent vein about 9.0 times longer than second abscissa of medial vein, 1.3 times longer than first radiomedial vein, 0.6 times as long as basal vein. Distance from nervulus to basal vein 0.6 times nervulus length. Hind wing 6.5 times longer its maximum width. Recurrent vein straight, weakly antefurcal, pigmented.

Legs. Fore tarsus 2.3 times longer than fore tibia. Hind coxa 1.5 times longer its maximum width (with tubercle), almost as long as propodeum. Hind femur 4.1 times longer its width. Hind tarsus 1.1 times longer than hind tibia. Second segment of hind tarsus 0.45 times as long as basitarsus, 1.8 times longer than fifth segment (without pretarsus).

Metasoma 1.1-1.3 times longer than head and mesosoma combined. First tergite rather distinctly and linearly widened basally, then weakly and almost linearly widened almost from base to subapex, weakly narrowed apically, with two short and wide oblique furrows in apical quarter. Maximum width of first tergite 1.8 times its minimum width; length 1.9 times its apical width. Median length of second tergite 0.7 times its basal width, 1.2 times length of third tergite. Ovipositor sheath 0.9 times as long as body, 1.6 times longer than metasoma, 2.7 times longer than mesosoma, 1.2 times longer than fore wing.

Sculpture and pubescence. Vertex densely and very finely aciculate with small and dense punctation between striae; frons with coarse and curved transverse striation; entire face densely rugulose-granulate; temple with rather fine but dense curved striae with punctation between them. Mesoscutum densely and finely granulate, with small sparse punctation and with two distinct carinae weakly convergent posteriorly; narrow area in medioposterior half of mesoscutum with rugosity around carinae. Scutellum rather densely and finely punctate. Mesopleuron mostly smooth but with very fine punctation. Propodeum almost entirely rugoseareolate, with areas delineated by fine carinae; areola wide, about 1.5 times longer than wide; basal carina about as long as anterior fork of areola. Entire hind coxae finely and densely punctate. Entire first tergite coarsely rugose-areolate; second tergite medially widely rugose-areolate, laterally striate-rugulose. Third tergite undulately rugulose-striate with additional dense gran-

Рис. 14-30. Rasnitsynoryctes alexandri gen. et sp.n. (голотип, самка). 14 - переднее крыло; 15 - средняя часть переднего крыла; 16 - брахиальная ячейка переднего крыла; 17 - заднее крыло; 18 - гамули; $19-$ задняя голень; $20-$ задний тазик; 21 задние тазик, вертлуг, вертлужек и бедро; 22 - три вершинных членика задней лапки; 23,24 - внутренняя шпора задней голени; 25 - метасома сбоку; 26 - вершинная часть метасомы сбоку; 27 - вершина яйцеклада сбоку; 28 - первый тергит метасомы сверху; 29 - второй и третий тергиты метасомы сверху; 30 - вершинные тергиты метасомы сверху. 
ulation in basal 0.7 , only densely granulate in subapical 0.2 , smooth in apical 0.1 . Fourth to sixth tergite very densely granulate, often with basal rugulosity, smooth in posterior $0.2-0.5$. Entire vertex with dense and semierect short setae, with additional sparse and almost erect long setae. Entire mesoscutum with very dense and semi-erect yellow setae. Hind tibia dorsally with very dense and semi-erect short setae, with additional sparse and semi-erect long setae; length of long setae 0.5-0.9 times maximum width of hind tibia.

Colour. Head and mesosoma black, propodeum dorsally reddish brown or dark reddish brown. First metasomal tergite reddish brown, remaining tergites black or almost black, third and fourth tergite apically dark reddish brown, fifth tergite apically light reddish brown to whitish, sixth and seventh tergite whitish in apical halves; metasoma ventrally mostly whitish yellow. Antenna black, two basal segments dark reddish brown. Palpi pale yellow. Fore leg brownish yellow, tarsus brown. Middle legs yellowish brown, femur apically brown, tarsus light brown. Hind coxa, trochanter, trochantellus and basal 0.7 of femur light brown, apical 0.3 of hind femur, tibia and tarsus brown or dark brown, tibia yellow in basal 0.2. Ovipositor sheath black. Fore wing faintly darkened, veins dark brown, parastigma brownish yellow. Pterostigma dark brown, yellowish brown apically.

Male. Unknown.

ACKNOWLEDGEMENTS. The present work was partly supported by grants from the Russian Foundation for Basic Research (No. 10-04-00265) and the Presidium RAS Program "Origin of the Biosphere and Evolution of Geo-biological Systems".

\section{References}

Belokobylskij S.A. 2002a. Two new Oriental genera of Doryctinae (Hymenoptera, Braconidae) from termite nests // Journal of Natural History. Vol.36. P.953-962.

Belokobylskij S.A. 2002b. The genus Halycaea Cameron (Hymenoptera: Braconidae: Doryctinae) in the Oriental Region // Zoologische Mededelingen. Vol.76. No.6. P.61-77.

Belokobylskij S.A. 2005a. New genus and new subgenus of subfamily Doryctinae (Hymenoptera: Braconidae) from the Old World fauna // Annales de la Société entomologique de France (n.s.). T.40 (2004). No.2. P.199-204.

Belokobylskij S.A. 2005b. Two new taxa of subtribe Rhaconotina (Hymenoptera: Braconidae, Doryctinae, Doryctini) from Africa, with a key to subtribe genera // Annales de la Société entomologique de France (n.s.). T.40 (2004). No.2. P.205-210.

Belokobylskij S.A. 2006. Neoheterospilus gen.n., a new genus of the tribe Heterospilini (Hymenoptera: Braconidae, Doryctinae) with highly modified ovipositor and a worldwide distribution // Insect Systematics and Evolution. Vol.37. P.149-178.

Belokobylskij S.A. 2008a. A new genus of the tribe Doryctini (Hymenoptera, Braconidae, Doryctinae) // Zoosystematica Rossica. Vol.17. No.1. P.123-130.

Belokobylskij S.A. 2008b. Ryukyuspathius, a new peculiar genus of the tribe Spathiini (Hymenoptera: Braconidae: Doryctinae) from Japan // Annales zoologici, Warszawa. Vol.58. No.4. P.761-766.

Belokobylskij S.A., Chen X. 2006. Hecabolomorpha n.gen., a new Asian genus from the tribe Hecabolini (Hymenoptera: Braconidae: Doryctinae) // Annales de la Société Entomologique de France (n.s.). T.42. No.1. P.107-111.

Belokobylskij S.A., Iqbal M., Austin A.D. 2004. Systematics, distribution and diversity of the Australasian doryctine wasps (Hymenoptera: Braconidae: Doryctinae) // Records of the South Australian Museum Monograph Series. Vol.8. P.1-150.

Belokobylskij S.A., Maeto K. 2009. Doryctinae (Hymenoptera, Braconidae) of Japan. (Fauna mundi. Vol.1). Warszawa: Warshawska Drukarnia Naukowa. 806 p. 